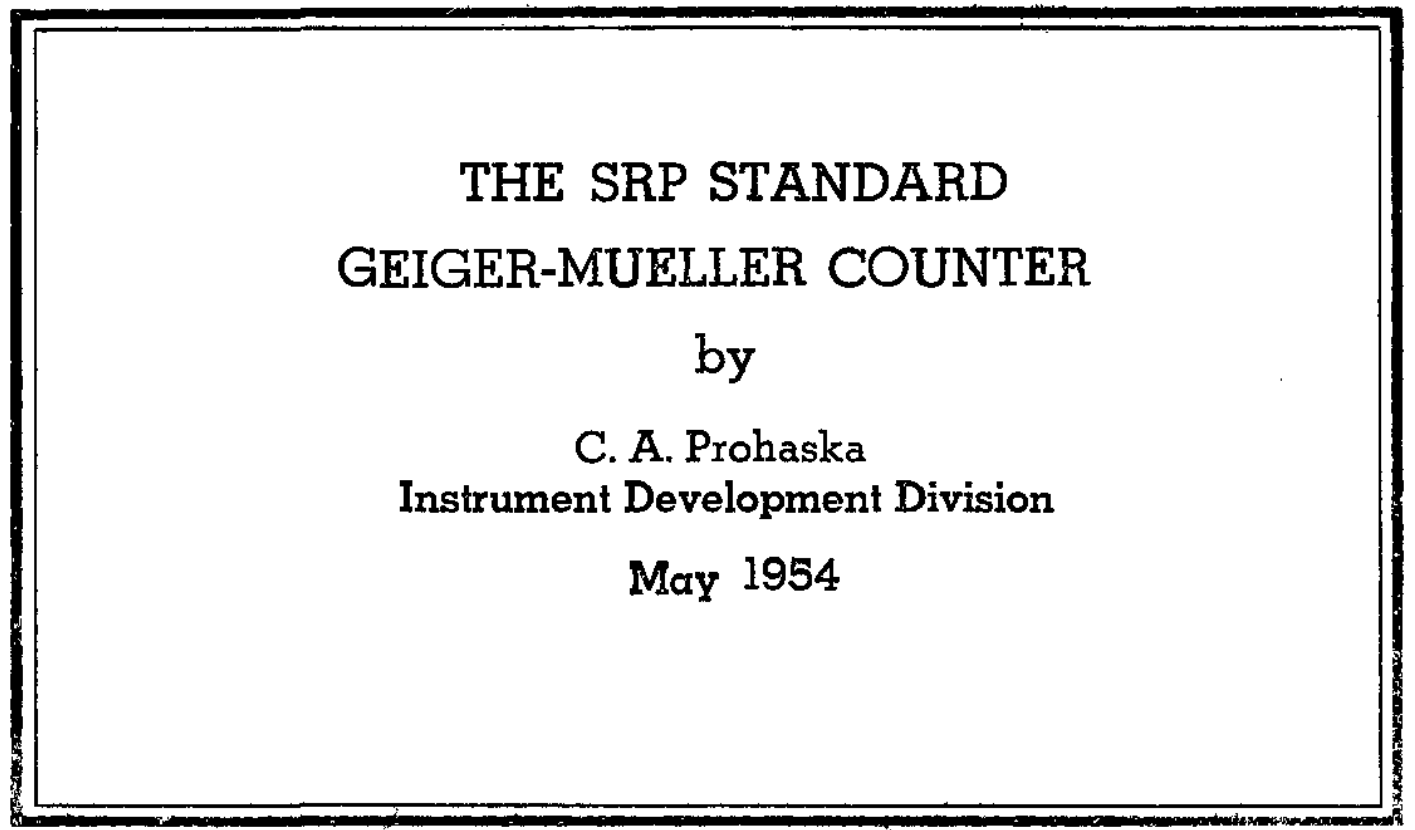

E. I. du Pont de Nemours \& Co.

Explosives Department - Atomic Energy Division Technical Division - Savannah River Laboratory 
THE SRP STANDARD GEIGER-MUELLER COUNTER

by

C. A. Prohaska

Instrument Development Division

May 1954

E. I. du Pont de Nemours \& Co.

Explosives Department - Atomic Energy Division

Technical Division - Savannah River Laboratory

Contract $\operatorname{AT}(07-2)-1$ with the

United States Atomic Energy Commission 


CC: J. W. Croach
M. H. Wahl - C. W. J. Wende
J. L. Hyde
C. A. Prohaska

SPECIAL DISTRIBUTION LIST

"FOR COUNTING ROOM MANUALS

\section{DP-6I THE SRP STANDARD \\ GEIGER-MUELLER COUNTER}

The attached report is the first of a serles which is being prepared on the various standard SRP counting room set-ups.

The G-M counter described here is defined as set \#20i in the "Catalog of Counting Room Instruments and Equipment" which is also written and maintained by C. A. Prohaska (773-A/TD 108, Ext. 3445).

Extensions or deletions to the special distribution 11st for count ing room manuals should be brought to the attention of $\mathrm{T}$. I. S.

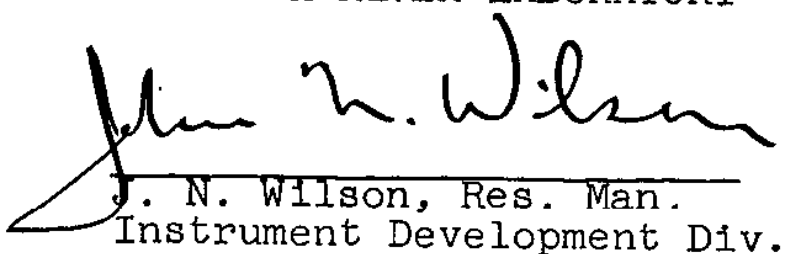


-1-5. Document Custodian, AEC, SROO, Augusta, Ga.

6. R. M. Evans - B. H. Mackey

7. W. C. Kay - M. H. Smith -

J. B. Tinker

8. I. Squires - H. Worthington

9. J. A. Burns

10. H. L. Greene - J. D Ellett

11. W. P. Overbeck

1 12. T. C. Evans - J. D. Cist

13. H. J. Bowman - W. M. SIoan

14. PRD File

15. M. H. Wahl -

C. W. J. Wende

16. J. W. Croach

17. J.N.Wilson

18. J. L. Hyde

19. C. A. Prohaska

20-86. Special Distribution for Counting Room Manuals

87-103. TIS File

104. TIS File Record Copy
Wilmington AED

i1

II

Wilmington Eng. Dept.

Savannah River Plant

11

"1"

"I

Savannah River Laboratory

II

if

.11

11

II

II 
20 - G. Dessauer - J. L. Crandall

$2)-J \cdot T$. Carleton - W. M. Heston

22 - L. Cathey -

$23-A: H$. Dexter

24 - J. W. Morris - R. I. Martens

$25-\mathrm{H}$. M. Kelley - C. H. Ice

26 - D. A. Brown

27 - A. L. Marston

28 -D. E. Waters - A. J. H111

$29-$ G. M. N1chols.

30- H. G. McLeod

3) - P. D. Deans

32 - C. T. Axelberg

з3 - W. L. Megaro

34 - I. S. Danser - J. K. Lower

उद-S. D. Smiley

36 - P. R. Moore

37 - J. J. Urban

$138-$ J. L. Shuder

$39-R \cdot$ B. Fenninger - W. R. Tyson

40 - C. M. Patterson - P. B. K'Burg

4/ - J. E. Gregory

$42-R$. D. McCrosky - K. E. Plumlee

$43-48-W$. C. ReIn1g (6)

4ng-5/-R. W. Thompson

$52-54-R$. B. McKellar (3)

$55-E$. L. Karlson

56-W. T. Christy, Jr.

57-59-E. L. Albenesius

$60-$ D. G. Ebenhack

61-G. B. O'Connor

$62-$ R. E. Wilmer

$63 \cdot$ R. W. Foster

$64-J . E$. Donahue

$65-$ A. A. Johnson - P. S. Shane -

$66-\mathrm{M}$. M: Mann

$67-\mathrm{L}$. C. Peery

68-69-E. B. Sheldon

$70-7-$ R. M. Girdler (2)

$72-74-T . K$. Conlon (3)

$75-79-\mathrm{R} . \mathrm{H}$. Dietz (5)

$80-82-\mathrm{J}$. J. Monahon

83-L. P. Skinner

$84-\mathrm{R}$. W. Hunt -

$85-C$. R. Bradford, M. D.

$86-$ W. D. Christy.
W-Pr=Qverbeck

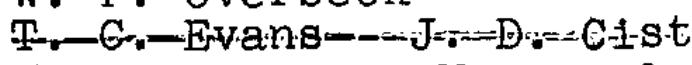

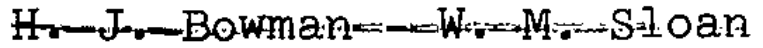

J.W-W.opoach

I. N-W.WEOn

I.-Ir,ehyde

G+A: $=$ Rrohaska 
DP $-6 I$

Page 3

INSTRUMENTATION

EXTERNAL DISTRIBUTION

105-110. Argonne National Laboratory

111-115. Armed Services Technical Information Agency, Dayton

116. Army Chemical Center

117. Army Medical Research Laboratory

118. Army Medical Service Graduate School

119. Atomic Bomb Casualty Commission, Washington

120. Atomic Energy Commission, Patent Branch

121-123. Atomic Energy Commission, Technical Ltbrary

124. Atomic Energy of Canada Iimited

125. Australian Embassy

126. Battelle Memorial Institute

127. Belgium, Centre d'Etudes pour les Applications de I'Energie Nuclea1re

128-130. Belgium, Union Miniere du Haut Katanga

131-134. Brookhaven National Laboratory

135. Bureau of Ships (Code 490)

136. Canadiar Jo1nt Staff (W)

137. Carbide and Carbon Chemicals Company, C-3I Plant

138-139. Carbide and Carbon Chemicals Company, K-25 Plant

140-144. Carbide and Carbon Chemicals Company, ORNL

145-148. Carbide and Carbon Chemicals Company, Y-12 Plant

149-150. Carnegie Institute of Technology

151-154. Chalk River Project, Canada

155. Chicago Patent Group

156. Columbia University (Dr. Falila)

157-158. Columbia University (Dr. Hassialis)

159. Columbia University (Dr. Havens)

160-161. Consolidated Vultee Aircraft Corporation

I62. Department of Army, Office of Ordnance Research

163. Department of Navy, Op-36

164. Department of Navy, Code 811

165. Division of Raw Materials, Denver

166. Division of Raw Materials, Ishpeming

167-168. Dow Chemical Company, Midiand

169. Dow Chemical Company, Rocky Flats

170. Eldorado Mining and Refining Limited

171. Frankford Arsenal

172-173. General Electric Company (ANPP)

174-175. General Electric Company, Richland

176-178. Goodyear Atomic Corporation

179. Harshaw Chemical Corporation

180-181. Iowa state College

182. Italy, Centro Italian Studi Experienze

183. Kaiser Engineers

184. Kansas City Operations Branch 


\section{EXTERNAL DISTRIBUTION (Continued)}

\section{Kirtland Air Force Base}

186-188. Knolis Atomic Power Laboratory

189-190. Los Alamos Scientific Laboratory

191. Mallinckrodt Chemical Works

192. Massachusetts Inst1tute of Technology (Dr. Hardy)

193. Massachusetts Institute of Technology (Dr. Kaufmann)

194. Mound Laboratory

195. National Advisory Committee for Aeronautics, Cleveland

196-197. National Bureau of Standards, Atomic Energy Project

198. National Bureau of Standards, Library

199. National Lead Company of Oh1o

200. National Research Corporation

201-203. National Research Counc1l, Canada

204. Naval Medical Research Institute

205-207. Naval Research Laboratory

208. New Brunswick Laboratory

209. Newport News Shipbuilding and Dry Dock Company

210-213. New York Operations office

214-215. North American Aviation, Inc.

216. Nuclear Development Associates, Inc.

217. Oak Ridge Institute of Nuclear Studies

218-221. Phillips Petroleum Co.

222-223. Public Health Service

224. Sandia Corporation

$225-299$.

300.

301 .

302 .

$303-317$

$318-319$.

$320-321$.

322.

Technical Information Service, Oak Ridge

The Surgeon General

Tokyo University

United Aircraft Corporation

United Kingdom Scientific Mission

U. S. Geological Survey (Mr. Butler)

U. S. Naval Radiological Defense Laboratory

UCLA Medical Research Laboratory

323-324. University of California Radiation Laboratory

325-327. University of California Radiation Laboratory, Livermore Site

328-329. University of Michigan (Dr. Gomberg)

330-331. University of Rochester, Atomic Energy Project

332. University of Tennessee

333. University of Utah

334. University of Washington (Dr. Manley)

335. Vitro Corporation of America

336. Walter Kidde Nuclear Laboratories, Inc.

337. Watertown Arsenal

338. Western University

339-342. Westinghouse Electric Corporation

343. Wright Air Development Center

344. Yale University (Gregory Bre1t)

345. Yale University (Dr. Wadey) 


\section{ABSTRACT}

The operating characteristics of the SRP standard GM counter were investigated. Plateaus are at least 150 volts long, with essentlally zero slope. Reproducibility and background are satisfactory for this type of counter. The colncidence correction is less than one-half per cent per 103 counts per minute. 
INTRODUCTION . . . . . . . . . . . . . . . . Page

SUMMARY AND CONCLUSIONS . . . . . . . . . . 7

EXPERIMENTAL WORK ............... 8

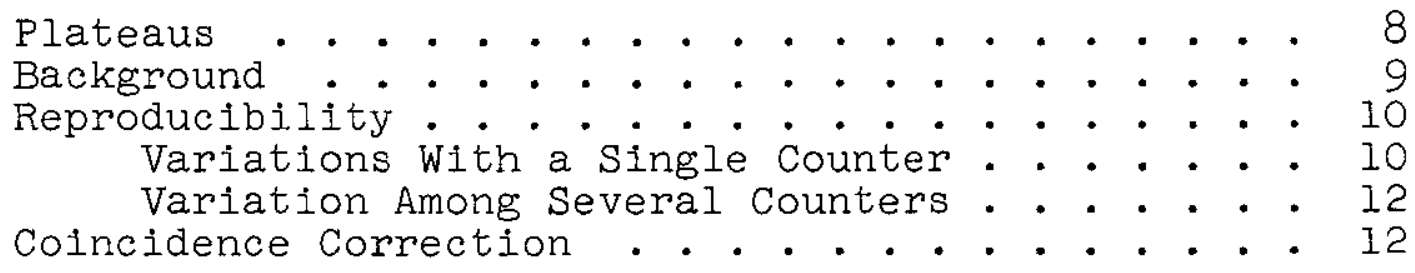

BIBLIOGRAPHY ................ . . 14

APPENDIX ................... 24

Table of Coincidence Corrections . . . . . . 25

LIST OF FIGURES AND TABLES

Figure 1. Photograph of the Standard GM Counter. . 15

Figure 2 GM Tube Plateaus at Various Counting

Figure 3 Rise of Threshold Voitage With Age of

Figure 4 Errors Introduced by Using "Table of Coincidence Corrections" to correct Observed Correct Rate ........ 19

Table I Variation in Counting Rate with Various

Table II Variation in the Counting Rate with a

Table III Variation in Counting $\dot{\text { Rate }}$ Between:

Table IV Counting Rate of Paired Sources : $: .: 24$ 
THE SRP STANDARD GM COUNTER

\section{INTRODUCTION}

This investigation was part of a program to determine the characteristics and limitations of the various types of counting equipment to be used at the Savannah River Plant.

Performance of the Geiger-Mueller counter (consisting of a Tracerlab CC-10 scaler, a Tracerlab TGC-1 or TGC-2 GM tube, and a Technical Associates LS-6 lead shield) is described in the present report. GM counters are generally useful in detecting beta and/or gamma radiation.

\section{SUMMARY AND CONCLUSIONS}

Within the limitations discussed below, the GM counter was found satisfactory for general use at the Savannah River Plant for counting rates up to $10^{4}$ counts per minute. It may be used at higher counting rates, but possible errors in reproducibility, after coincidence correction, become appreciable (greater than $2 \%$ ).

Counting rates with different counters frequently vary by $\pm 10 \%$. The effects of aging must be corrected by frequent checks with standard sources. The conclusions are based on: the following test results.

\section{PLATEAUS}

Plateaus on satisfactory GM tubes are at least 150 volts long, with practically zero slope over this region. Plateaus begin about 100 volts above threshold, but threshold voltage varies from tube to tube as much as 200 volts. Threshold and plateau gradually shift to higher voltages as the tube ages.

\section{BACKGROUND}

Background varies depending upon the level of radioactivity in the vicinity of the GM counter. The natural background to be expected is about 20-25 counts per minute. This may rise to 40-50 counts per minute if hard gamma sources (Co60 for example) are brought near the shield. 
REPRODUCIBILITY

With a single counter, the variation of replicate counts was somewhat greater than would be expected from statistics. The additional variability was found to becharacteristic of the GM counter.

The maximum range of counting rates for any single source as measured on six counters was $23 \%$. The range was generally in the neighborhood of $20 \%$ at counting rates between 6,000 and 57,000 counts per minute.

COINCIDENCE CORRECTION

The coincidence correction can be calculated from the following equation:

$$
\begin{aligned}
& N=R+2.211\left(10^{-6}\right) R^{2}+2.505\left(10^{-11}\right) R^{3} \\
& \text { Where } N=\text { corrected counting rate } \\
& R=\text { observed counting rate }
\end{aligned}
$$

For $R=5 \times 10^{4}$ counts per minute, the expected error in $N$ is less than 10 per cent. A table of coincidence corrections for counting rates up to 50,000 counts per minute is included in the Appendix to this report.

\section{EXPERIMENTAL WORK}

The Geiger-Mueller counter consists of the following major components:

1 - scaler (Tracerlab Type CC-10)

1 - lead shield (Technical Associates Type LS-6)

1 - GM tube (Tracerlab Type TGC-1 or TGC-2)

Figure 1 is a photograph of the complete GM counter

\section{PLATEAUS}

The plateau of the GM tube used in the standard GM counter should have (manufacturer's specifications) a plateau at least 300 volts long with a slope of approximately one per cent per hundred volts. A plateau (plotted by the manufacturer) is supplied with each GM tube. These plateaus are determined with a Co60 source giving 10,000 - 15,000 counts per minute at a scaler sensitivity of 0.35 volts(1). The two types of tubes, TGC-1 and TGC-2, have very similar plateaus and differ only in window thickness. The counters tested included both types. 
The present investigation indicates that if the above conditions are duplicated, the manufacturer's plateaus can be checked quite closely. It is important, however, that the counting rate be held below 15,000 counts per minute. Reliable plateaus were not obtained with sources that gave high counting rates. Figure 2 indicates what happens at higher counting rates. The four plateaus shown were determined with the same counter and source, only the geometry being changed. The lowest plateau (slope $\cong 0 \%$ ) was determined with the source on shelf 5 of the sample holder, while the highest plateau (slope $\cong 11 \%$ ) was determined with the source on shelf 1 . (the top shelf). Figure 2 shows how the plateau is distorted at higher counting rates.

The lower end of the plateau lies about 100-I50 volts above the threshold voltage. The threshold voltage varies from tube to tube, but was between 1100 and 1300 volts for all of the new tubes that were tested. A typical series of plateaus is presented in the following table:

Coliection Anode Voltage

1500

1450

1400

1350

1300

1250

1200

1150
Counts per Minute on Each of Five Different GM Tubes

As the GM tube ages, the threshold voltage, as well as the operating voltage, rises. A GM counter was started counting continuously, at a rate of about 13,800 counts per minute (approximately 2 x 107 counts per day). A plateau was run each day. The observed rise of threshold voltage is plotted in Figure 3 .

\section{BACKGROUND}

The natural background for the standard GM counter lay between 20-25 counts per minute for all counters tested. The background is very sensitive to outside sources of radiation.

The background of a counter increased from 24 counts per minute to 43 counts per minute when a co60 source was placed on the bench outside the shield. The strength of this source was 13,800 counts per minute on shelf 5 . The background of the same counter increased from 24 counts per minute to 27 
counts per minute when an ordinary wrist watch with a luminous dial was taped to the outside of the shield.

\section{REPRODUCIBILITY}

Variations with a Single Counter In collecting the data for calculating the coincidence correction, nine coo sources were each counted three times (10-minute counts) with six different counters. The variation of the three counts from the average of the three was considerably higher than would be expected from statistics. The two relations:

$$
\sigma_{1}=\sqrt{\frac{\mathrm{N}-1}{\mathrm{~N}}} \cdot \frac{1.65}{\sqrt{\mathrm{M}}} \quad \sigma_{2}=\sqrt{\frac{\mathrm{N}-1}{\mathrm{~N}}} \cdot \frac{1.96}{\sqrt{\mathrm{M}}}
$$

were used to calculate the expected deviations from the average at the 90\% and 95\% confidence levels, where $\mathrm{M}$ is the average number of counts per observation, and $\mathrm{N}$ is the number of observations. Of the 162 counts made, only 129 (80\%) were within the deviation $\sigma_{1}$ and 139 (86\%) were within the deviation $\sigma_{2}$

This complete series of counts is shown in Table 1. The values which lie outside the expected deviation at the $90 \%$ confidence level are starred. It will be noticed that more values outside the expected deviation were obtained with counter no. 5 than with any other counter. If we omit the results obtained on counter no. 5 completely, the figures at the $90 \%$ and $95 \%$ confidence levels become $83 \%$ and $90 \%$.

A more complete statistical analysis of these data was made using a variance ratio (F) test. This was done in the following manner:

For each of the 54 sets of three counts, the three deviates were calculated:

$$
t_{i}=\sqrt{\frac{3}{2}} \quad \frac{M_{i}-M}{\sqrt{M}} \quad i=1,2,3
$$

where

$$
\bar{N}=\frac{\sum_{i=1}^{3} M_{i}}{3}
$$

From these deyiates, the variance was calculated:

$$
S^{2}=F=\frac{\sum_{i=1}^{162} t_{i}^{2}}{162}
$$


For the data in Table I, $F=3.3$, which is to be compared. With the value of 1.3 listed in a standard $F$ table $(2)$ for the $1 \%$ confidence limit.

The high value of $F$ indicates a very low probability (much less than $1 \%$ ) that the observed variations could be statistical in nature.

In another series of counts, a single source was counted seventy-six times on the same counter. Included were one 100-minute count, fifteen 10-minute counts, thirty 3-minute counts, and thirty l-minute counts. The results of these counts are given in Table II. Again, the starred values are those which lie outside the expected deviation at the $90 \%$ confidence level.

The observed variation in counting rate was as follows:

\begin{tabular}{|c|c|c|}
\hline & & Maximum \\
\hline 10-minute & counts (15) & $\begin{array}{l}+0.38 \% \\
-0.65 \%\end{array}$ \\
\hline 3-minute & counts $(30)$ & $\begin{array}{l}+0.96 \% \\
-0.88 \%\end{array}$ \\
\hline I-minute & counts $(30)$ & $\begin{array}{l}+2.1 \% \\
-1.6 \%\end{array}$ \\
\hline
\end{tabular}

The expected statistical variations at this counting rate $\left(13,500\right.$ counts per minute) for $90 \%$ confidence $\left(\sigma_{1}\right)$ are:

$$
\begin{array}{ll}
10-\text { minúte count } & \pm 0.44 \% \\
3 \text {-minute count } & \pm 0.83 \% \\
1 \text {-minute count } & \pm 1.44 \%
\end{array}
$$

Again, less than $90 \%$ of the counts were within the expected deviation. These data were also analyzed by means of the variance ratio (F) test, but the results of this analysis were inconclusive, perhaps because fewer data were available. The decrease in counting rate with increasing time of count, noted elsewhere(3), is apparent from the data in Table II.

It was concluded that counting rates measured with the standard GM counter are subject to greater variability than would be expected from statistical considerations. 
Variation Among Several Counters Nine sources were counted on six counters having completely different components. The results are presented in Table III. Each count rate is the average of three 10-minute counts. Also listed is the count rate of each source averaged over the six counters. The maximum positive and negative deviations from the average are included. In general, agreement of better than $10 \%$ among counters cannot be expected.

\section{COINCIDENCE CORRECTION}

The method of paired sources (4) was used to determine the colncidence correction. A relationship between the observed counting rate " $R$ " and the true counting rate " $N$ " is:

$$
N=R+\tau R^{2}+v R^{3}
$$

Three "paired" sources were counted, and the values of $\tau$ and $v$ which best fit the experimental data were determined by a method of least squares.

The experimental data are given in Table IV. Each counting rate is the average of three lo-minute counts. The first two numbers are the individual counting rates of each one of a pair, and the third number is the combined counting rate. These data were then used to solve for $\tau$ and $v$. The values appropriate for each counter are summarized below:

Counter

1
2
3
4
5
6

Average of the six counters

$\tau \times 10^{6}$

1.622

3.373

2.550

0.245

1.583

3.892 v $\times 10^{11}$

0.293

2.769

0.922

6.836

3.783

0.427

A comparison was then made between each of the six specific equations calculated for the six counters, and the general equation calculated from the average of the data from the six counters. It was assumed that the "true" counting rate was the observed counting rate corrected by the specific equation for the particular counter. Calculations were then made to determine the error introduced in the "true" counting rate, for each of the six counters, when the observed counting rate was corrected by using the general equation. Figure 4 is a plot of this error versus counting 
rate. The maximum error is appreciable, approaching $10 \%$ of the "true" counting rate at 50,000 counts per minute.

A table of coincidence corrections for counting rates up to 50,000 counts per minute is included in the Appendix.

This table was calculated from the general equation determined for the six counters, and should be used with the knowledge that even at moderate counting rates ( $1 . e ., 20,000$ counts per minute) the corrected value may be in error by several per cent.

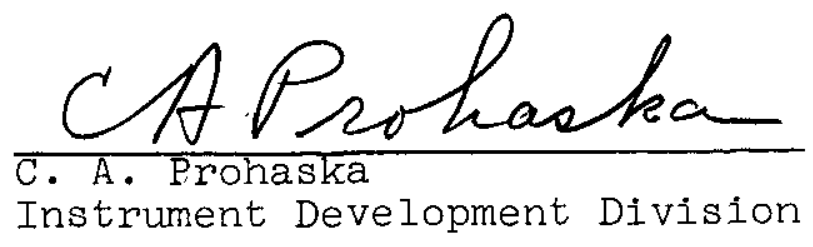




\section{BIBLIOGRAPHY}

1. Low, F. H. personal communication, February: 1954.

2. Goulden, C. H. Methods of Statistical Analysis New York: John Wiley \& Sons (1952). Table A-6, page 446.

3. Prohaska, C. A. The SRP Standard Windowless Flow Counter E. I. du Pont de Nemours \& Co. DP-45, April, 1954.

4. Kohman, T. P. A General Method for Determining Coincidence Corrections of Counting Instruments. United States Atomic Energy Commission MDDC-905, June $13,1945$. 


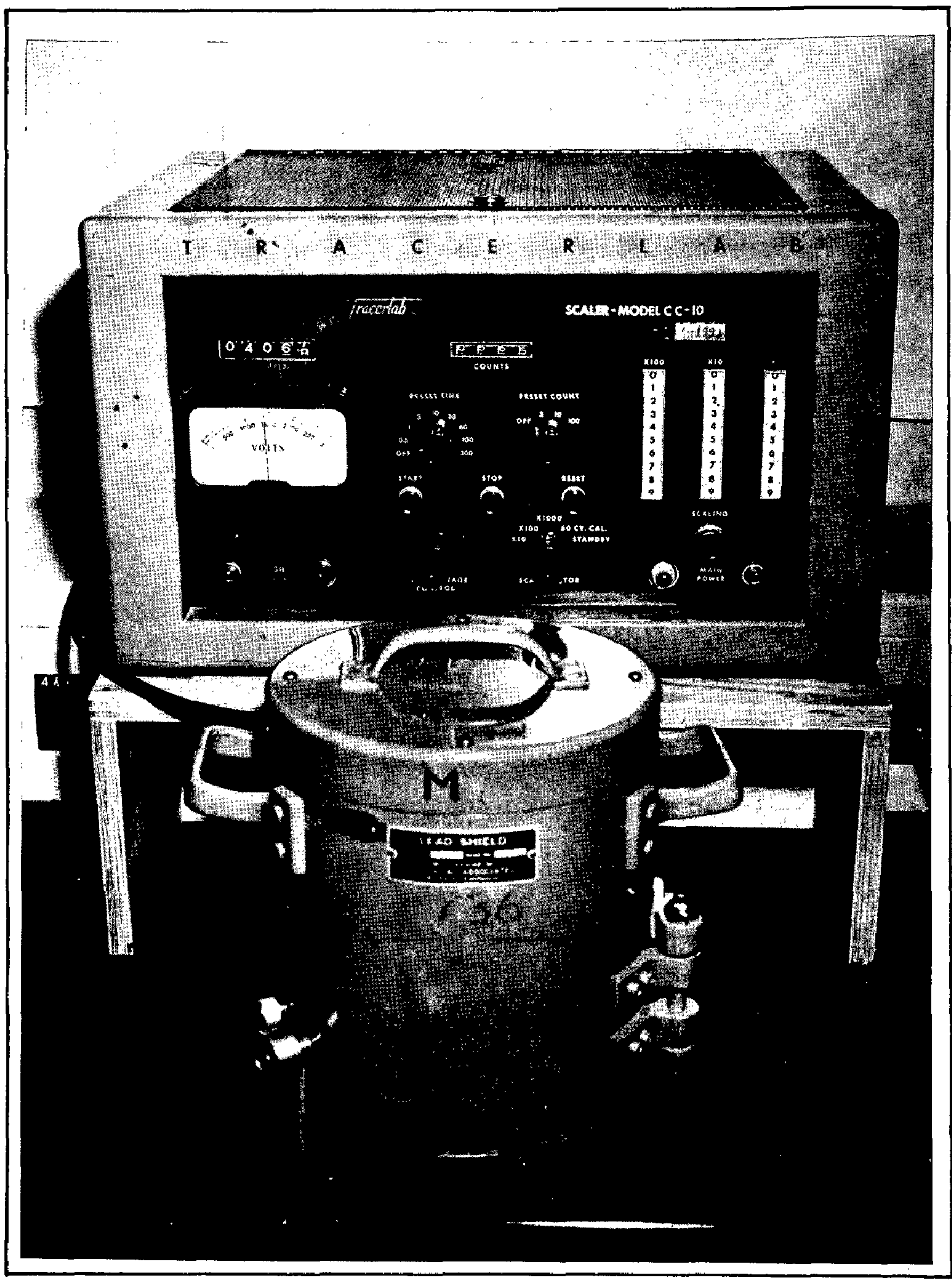




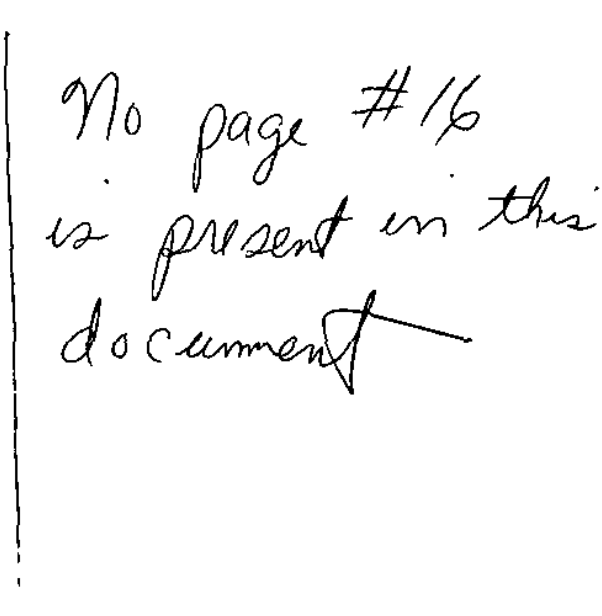

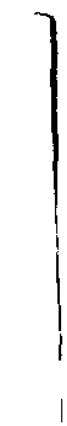


Figure 2

DP -61

Page 17

THOUSANDS OF COUNTS PER MINUTE

200

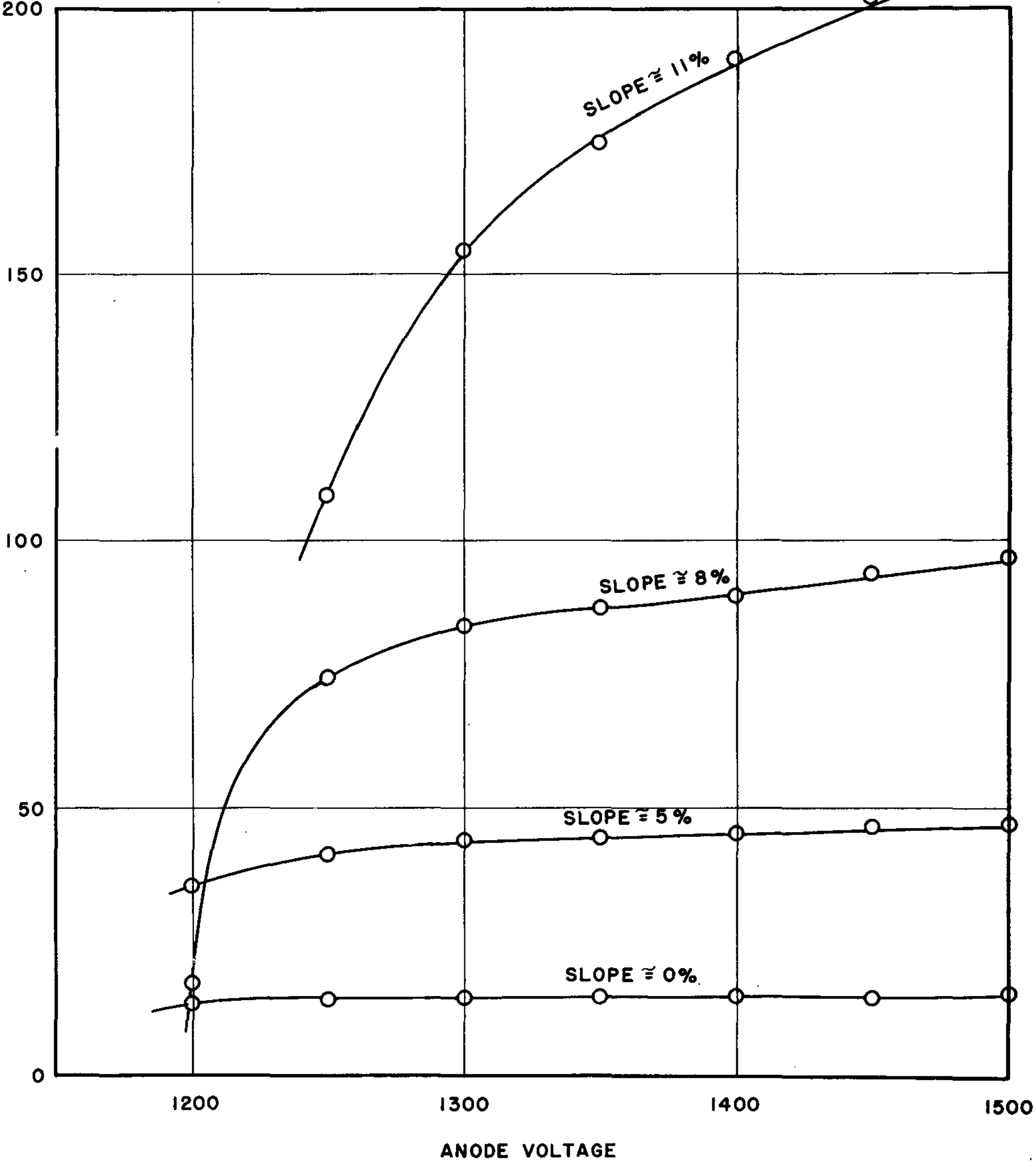

$x$ M TUBE PLATEAUS AT VA'IOUS $\because$ UNTIN 


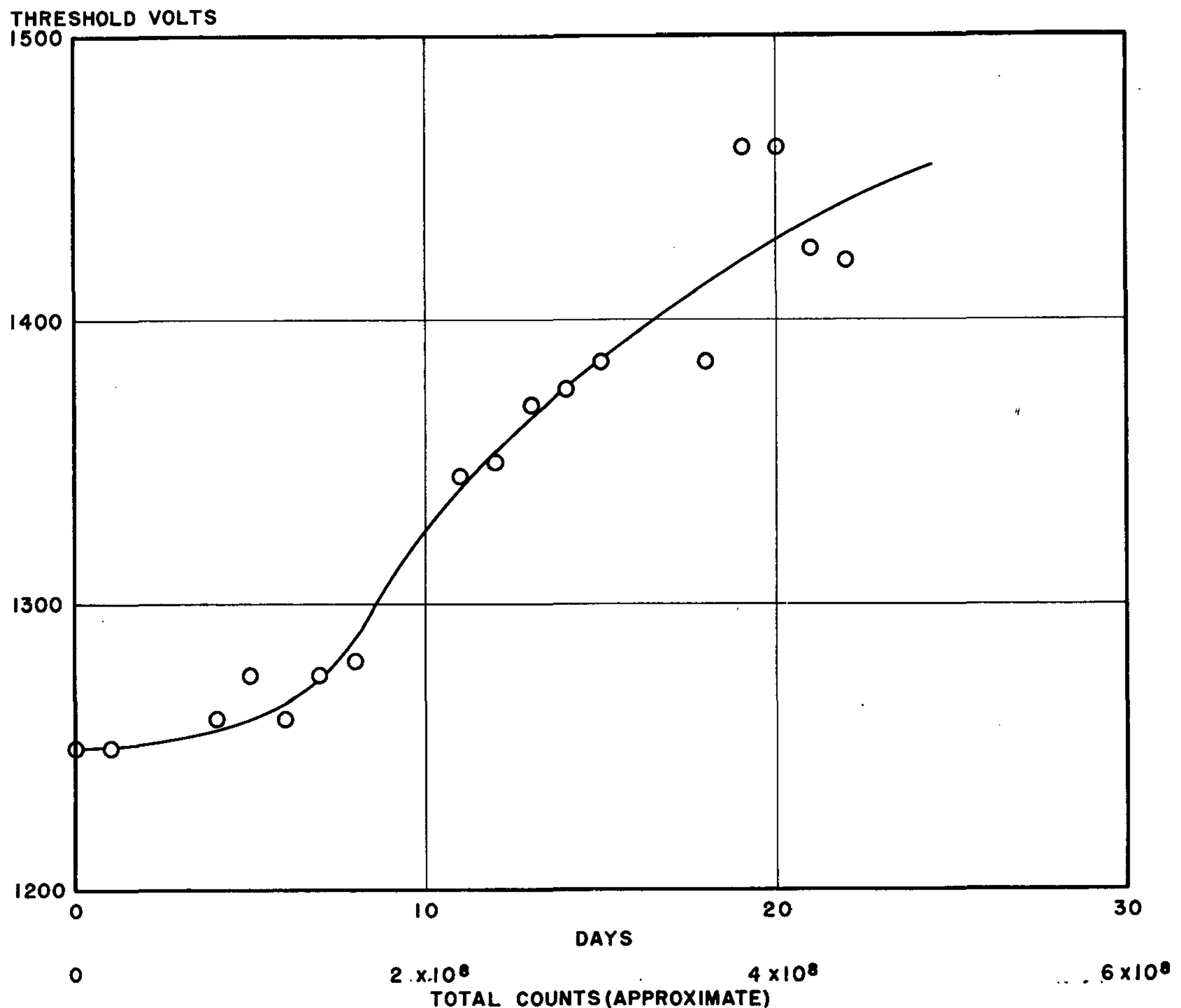
TOTAL COUNTS (APPROXIMATE)

RISE OF THRESHOLD VOLTAGE WITH GM TUBE AGE 


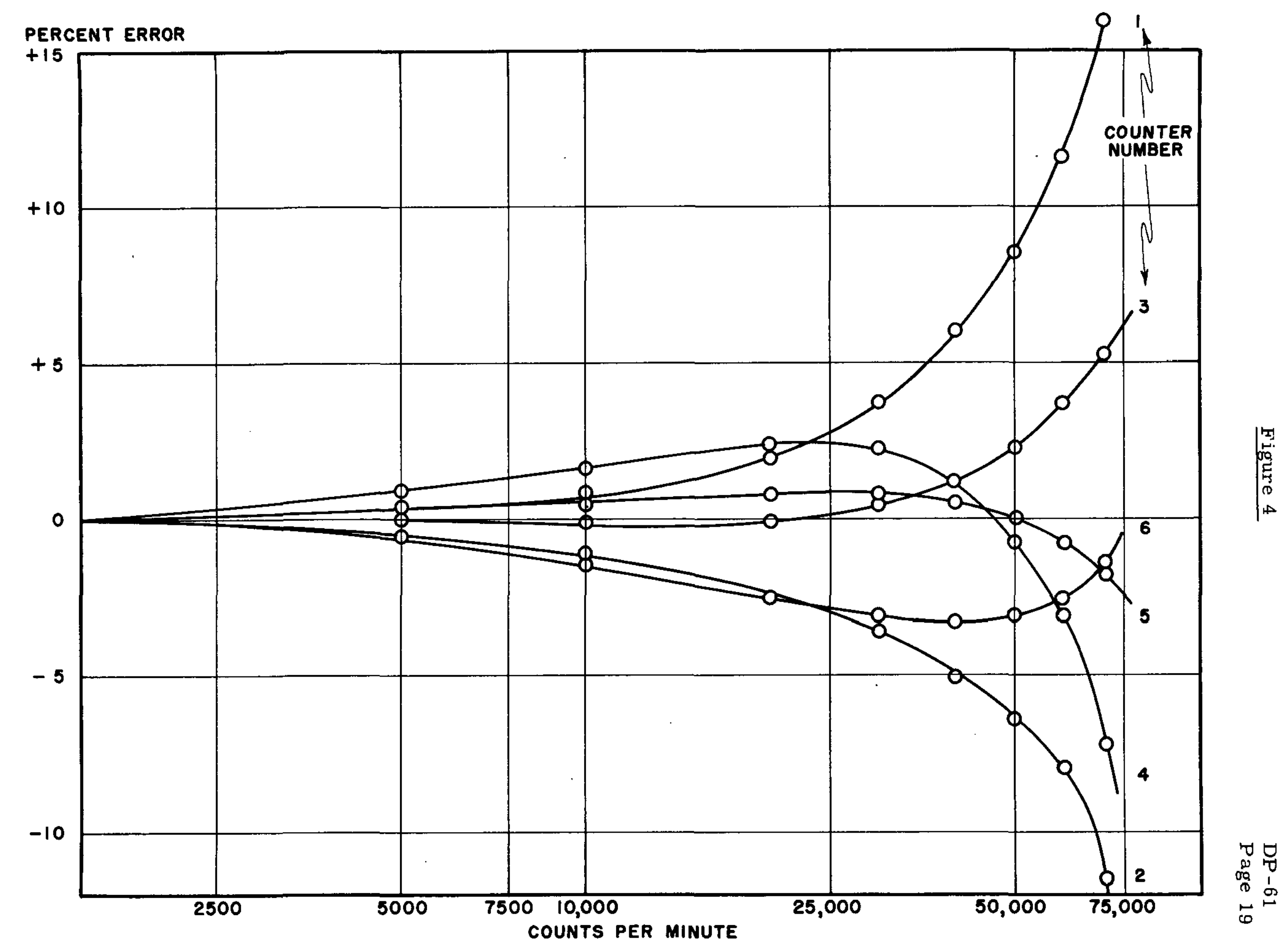

ERROR INTRODUCED BY USING "TABLE OF COINCIDENCE CORRECTIONS" TO CORRECT OBSERVED COUNT RATE 
$D P-6 I$

Page 20

Table I

VARIATION IN COUNTING RATE WITH VARIOUS SOURCES (TEN MINUTE COUNTS)

Counter

Number

1

$$
\begin{aligned}
& 7077 \\
& 5543 \\
& 12427 \\
& 14717 \\
& 15194 \\
& 29181 \\
& 31999 \\
& 29018 * \\
& 58009
\end{aligned}
$$

2

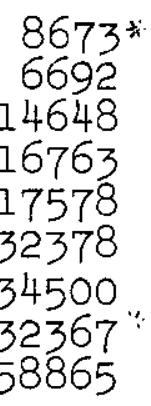

3

4

6366

14217

16989 *

17568

$33313:=$

35999

32270

$62416 *$
Three Observed Values of Counting Rate

(counts per minute)

7085

5510

12401

14665

15229

29145

31895

$28817^{*}$

$57794 *$

8517

14652

16715

17512

32324

34428

$32170 \%$

58775

32323
58879

$8379 \quad 8296$

7271

5873

13059

15444

15919 :

29942

32584 *

$30233 \%$

55348
6367

14227

$16860 *$

17593

33193

35899

32267

62637

7302

5850

13059

15453

16013

29922

$32410 \div$

30356

55246
8329

6346

14226

16909

17591 .

33132

35923

32300

62541

7332

5839

13010

15428

16034

29869

32479

30398

55219
Average Value of Counting Rate

7083
5526
12428
14671
15205
29181
31943
28913
57963

8547

6699

14627

16753

17559

32395

34468

32287

58840

8335

14223

16919

17584

33213

35940

32279

62531

7302
5854

13043

15442

15989

29911

32491

30329

55271 
DP-61

Page 21

TABLE I (Continued)

Counter Number

5

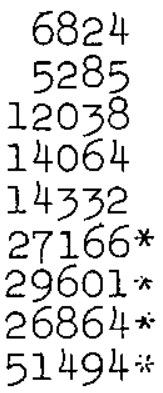

6

5
Three Observed Values of counting Rate (counts per minute)

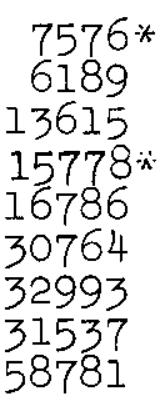

6796

5297

11999

14045

14290

27114

29496

$27511^{*}$

51468 ir

7651

6197

13597

15850

16783

30709

33001

31540

58772
6810

5268

11952

14026

14226 * $26942 *$ $29413^{*}$ $27618 \div$ 52169\%

\section{$7731 *$}

6205

13561

$15933^{*}$

16751

30650

33110

31470

$58614:$
Average Value of Counting Rate

6810
5283
11996
14045
14282
27074
29504
27331
51710

7653

6197

13591

15854

16774

30708

33035

31516

58723 
DP-61

Page 22

TABLE II

VARIATION IN THE COUNTING RATE WITH A SINGLE SOURCE

Counts per

100 minutes

1352163

Average

1352163

Average

Counts

per

minute

13522
Counts per

10 minutes

134821

135176

135306

$134532 *$

135553

134852

135800

135526

135929

135763

135681

135560

135290

135695

135793

135418

13542
Counts per

3 minutes

.40751

40584

40792

40724

40601

41027 *

$41065 *$

40409

40572

40316:

40887

40607

40848

40828

40397

40745

40522

40516

40769

40730

40515

40690

40802

40606

40447

40831

40688

40666

40518

40808

40675
Counts per

1 minute

13590

13727

13656

13733

13950\%

$13929:=$

13498

13476 :

13789

13781

13825

13698

$13980:-$

13701

13744

13608

13694

13730

13761

13621

13546

13518

13517

13638

13686

13668

13792

13559

13753

13618

13693 


\section{Table III}

VARIATION". OF COUNTING! RATE AMONG SEVERAL COUNTERS

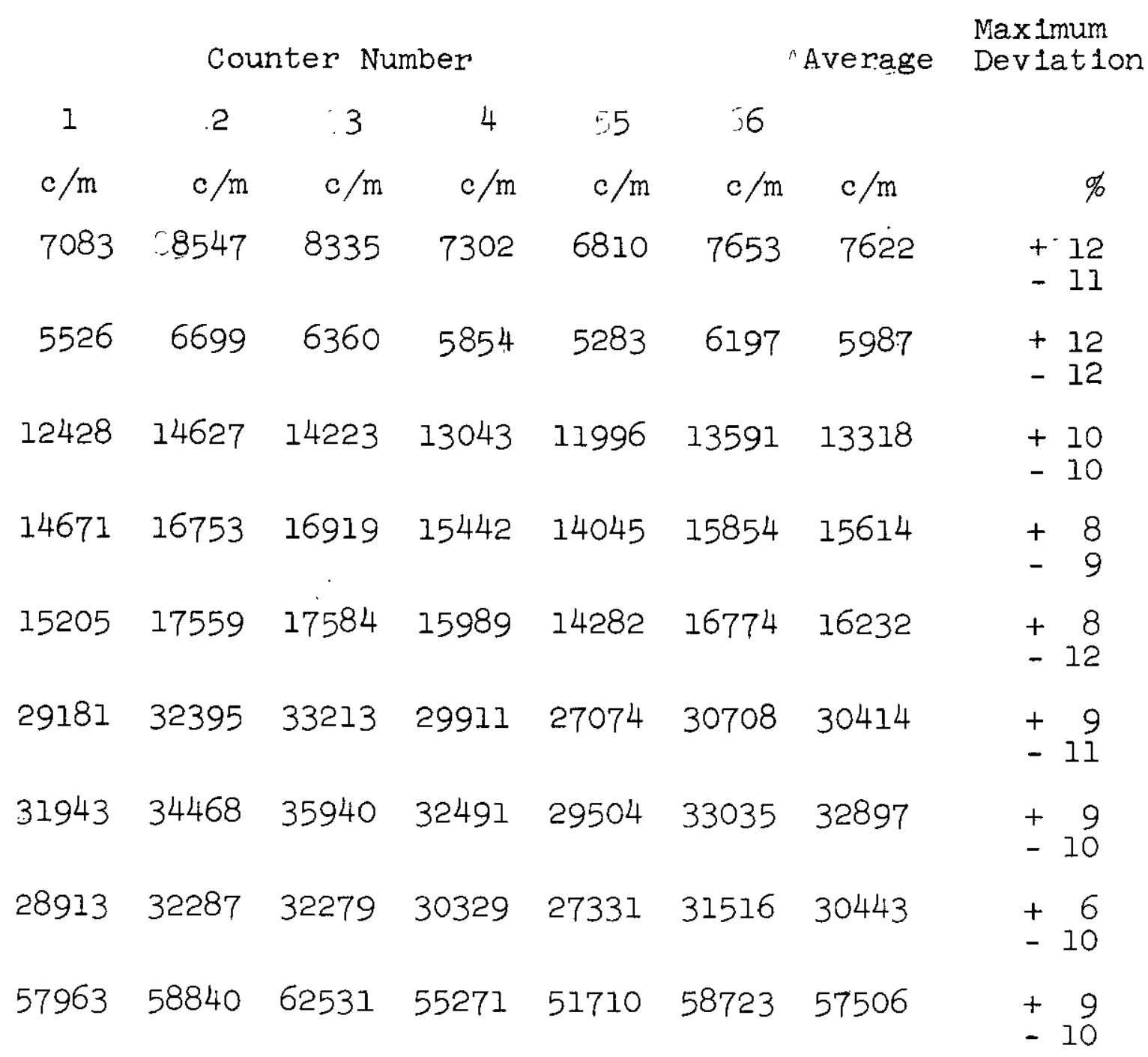


DP -61

Page 24

TABLE IV

COUNTING RATE OF PAIRED SOURCES

Counter

1

2

3

4

5

6

Pair 1

7083

5526
12428

8547

6699

14627

8335

6360

14223

7302

5854

13043

6810

5283

11996

7653
6197
13591
Pair 2

14671

15205

29181

16753

17559

32395

16919

17584

33213

15442

15989

29911

14045

14282

27074

15854

16774

30708
Patr 3j

31943

28913

57.963

34468

32287

58840

35940

32279

62531

32491

30329

55271

29504

27331

51710

33035

31516

58723 


\section{APPENDIX}

The attached table shows coincidence corrections versus observed counting rate for the standard GM counter. This table lists the correction to be added to the observed counting rate (in counts per minute) to obtain the "true" counting rate. Values for observed counting rates between 0 and 50,000 counts per minute are listed in units of 100 counts per minute. Interpolation is not necessary since an error of less than $0.1 \%$ is introduced by reading the coincidence correction to the nearest hundred counts.

The vertical columns of numbers are the observed counting rates in units of 1000 . Intermediate values in units of 100 run horizontaliy. The following example illustrates the use of the table:

Observed counting rate 9,273

Counting rate (to nearest hundred) 9,300

Correction (from table) 210

"True" counting rate 9,483 
TABLE OF COINCIDENCE CORRECTIONS FOR COUNTING ROOM SET UP \#2OI (GM Counter)

\begin{tabular}{|c|c|c|c|c|c|c|c|c|c|c|c|}
\hline & 000 & 100 & 200 & 300 & 400 & 500 & 600 & 700 & 800 & 900 & \\
\hline 0 & & 0 & 0 & 0 & 0 & 1 & 1 & 1 & 1 & 2 & 0 \\
\hline $\begin{array}{l}1 \\
2 \\
3 \\
4\end{array}$ & $\begin{array}{r}2 \\
9 \\
20 \\
37\end{array}$ & $\begin{array}{r}3 \\
10 \\
22 \\
39\end{array}$ & $\begin{array}{r}3 \\
11 \\
23 \\
41\end{array}$ & $\begin{array}{r}4 \\
12 \\
25 \\
43\end{array}$ & $\begin{array}{r}4 \\
13 \\
26 \\
45\end{array}$ & $\begin{array}{r}5 \\
14 \\
28 \\
47\end{array}$ & $\begin{array}{r}6 \\
15 \\
30 \\
49\end{array}$ & $\begin{array}{r}6 \\
16 \\
31 \\
51\end{array}$ & $\begin{array}{r}7 \\
18 \\
33 \\
53\end{array}$ & $\begin{array}{r}8 \\
19 \\
35 \\
56\end{array}$ & $\begin{array}{l}1 \\
2 \\
3 \\
4\end{array}$ \\
\hline 5 & 58 & 60 & 63 & 65 & 68 & 71 & 73 & 76 & 79 & 82 & 5 \\
\hline $\begin{array}{l}6 \\
7 \\
8 \\
9\end{array}$ & $\begin{array}{r}84 \\
116 \\
153 \\
196\end{array}$ & $\begin{array}{r}87 \\
120 \\
157 \\
201\end{array}$ & $\begin{array}{r}90 \\
123 \\
162 \\
205\end{array}$ & $\begin{array}{r}93 \\
127 \\
166 \\
210\end{array}$ & $\begin{array}{r}97 \\
130 \\
170 \\
215\end{array}$ & $\begin{array}{l}100 \\
134 \\
174 \\
220\end{array}$ & $\begin{array}{l}103 \\
138 \\
178 \\
225\end{array}$ & $\begin{array}{l}106 \\
142 \\
183 \\
230\end{array}$ & $\begin{array}{l}109 \\
146 \\
187 \\
235\end{array}$ & $\begin{array}{l}113 \\
149 \\
192 \\
240\end{array}$ & $\begin{array}{l}6 \\
7 \\
8 \\
9\end{array}$ \\
\hline 10 & 245 & 250 & 255 & 260 & 266 & 271 & 277 & 282 & 288 & 293 & 10 \\
\hline $\begin{array}{l}71 \\
72 \\
13 \\
14\end{array}$ & $\begin{array}{l}299 \\
360 \\
426 \\
499\end{array}$ & $\begin{array}{l}305 \\
366 \\
433 \\
507\end{array}$ & $\begin{array}{l}311 \\
373 \\
440 \\
515\end{array}$ & $\begin{array}{l}317 \\
379 \\
448 \\
523\end{array}$ & $\begin{array}{l}323 \\
386 \\
455 \\
530\end{array}$ & $\begin{array}{l}329 \\
392 \\
462 \\
538\end{array}$ & $\begin{array}{l}335 \\
399 \\
469 \\
546\end{array}$ & $\begin{array}{l}341 \\
406 \\
477 \\
554\end{array}$ & $\begin{array}{l}347 \\
413 \\
484 \\
563\end{array}$ & $\begin{array}{l}353 \\
419 \\
492 \\
571\end{array}$ & $\begin{array}{l}11 \\
12 \\
13 \\
14\end{array}$ \\
\hline 15 & 579 & 587 & 596 & 604 & 613 & 621 & 630 & 639 & 647 & 656 & 15 \\
\hline $\begin{array}{l}16 \\
17 \\
18 \\
19\end{array}$ & $\begin{array}{l}665 \\
758 \\
858 \\
965\end{array}$ & $\begin{array}{l}674 \\
768 \\
869 \\
977\end{array}$ & $\begin{array}{l}683 \\
778 \\
879 \\
988\end{array}$ & $\begin{array}{l}692 \\
788 \\
890 \\
999\end{array}$ & $\begin{array}{r}702 \\
797 \\
900 \\
1010\end{array}$ & $\begin{array}{r}711 \\
807 \\
911 \\
1022\end{array}$ & $\begin{array}{r}720 \\
817 \\
922 \\
1033\end{array}$ & $\begin{array}{r}730 \\
828 \\
933 \\
1045\end{array}$ & $\begin{array}{r}739 \\
838 \\
943 \\
1056\end{array}$ & $\begin{array}{r}749 \\
848 \\
954 \\
1068\end{array}$ & $\begin{array}{l}16 \\
17 \\
18 \\
19\end{array}$ \\
\hline 20 & 1080 & 1092 & 1104 & 1116 & 1128 & 1140 & 1152 & 1164 & 1177 & 1189 & 20 \\
\hline $\begin{array}{l}21 \\
22 \\
23 \\
24\end{array}$ & $\begin{array}{l}1202 \\
1331 \\
1468 \\
1613\end{array}$ & $\begin{array}{l}1214 \\
1344 \\
1482 \\
1628\end{array}$ & $\begin{array}{l}1227 \\
1358 \\
1496 \\
1643\end{array}$ & $\begin{array}{l}1240 \\
1371 \\
1511 \\
1658\end{array}$ & $\begin{array}{l}1252 \\
1385 \\
1525 \\
1673\end{array}$ & $\begin{array}{l}1265 \\
1399 \\
1540 \\
1689\end{array}$ & $\begin{array}{l}1278 \\
1412 \\
1554 \\
1704\end{array}$ & $\begin{array}{l}1291 \\
1426 \\
1569 \\
1719\end{array}$ & $\begin{array}{l}1305 \\
1440 \\
1583 \\
1735\end{array}$ & $\begin{array}{l}1318 \\
1454 \\
1598 \\
1750\end{array}$ & $\begin{array}{l}21 \\
22 \\
23 \\
24\end{array}$ \\
\hline \multirow[t]{2}{*}{25} & 1766 & 1782 & 1798 & 1814 & 1830 & 1846 & 1862 & 1878 & 1894 & 1911 & 25 \\
\hline & 000 & 100 & 200 & 300 & 400 & 500 & 600 & 700 & 800 & 900 & 赵 \\
\hline
\end{tabular}


Table of Coincidence Corrections for Counting Room set Up \#201 (GM Counter) - Continued.

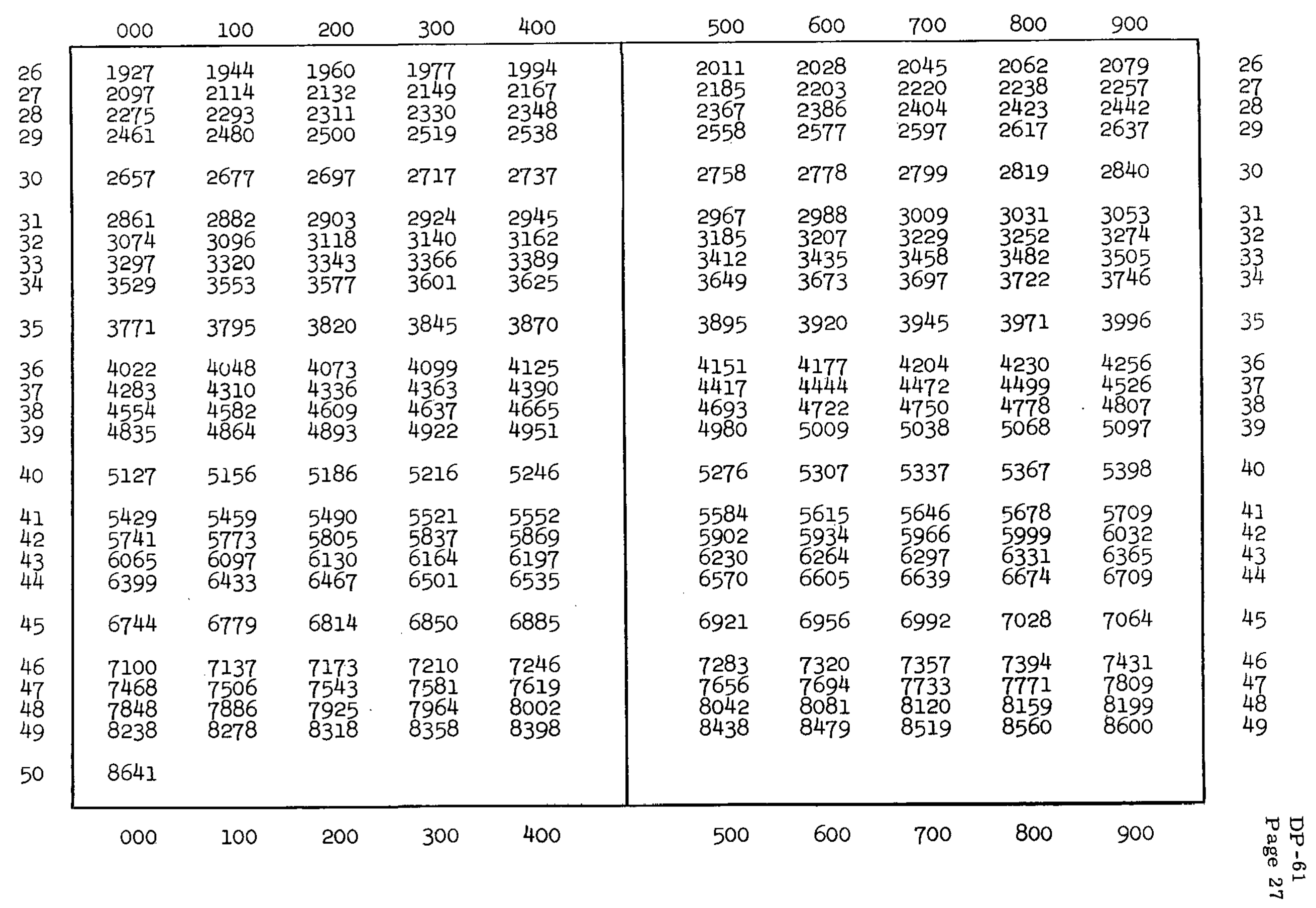

